\title{
THE EFFECTS OF MONETARY POLICY: A META-ANALYSIS
}

\author{
PAUL DE GRAUWE \\ Cláudia Costa StOrTi
}

\section{CESIFO WORKING PAPER NO. 1224 \\ CATEgory 6: Monetary Policy AND InTERnAtional Finance JUNE 2004}

Presented at CESifo Area Conference on Macro, Money and InTERnational FINANCE, FEBRUARY 2004

\footnotetext{
An electronic version of the paper may be downloaded

- from the SSRN website: www.SSRN.com

- from the CESifo website: www.CESifo.de
} 


\title{
The Effects of Monetary Policy: A Meta-Analysis
}

\begin{abstract}
In this paper we perform a meta-analysis of the effects of monetary policies on output and prices. We use a sample of published papers on the effects of monetary policies in different countries. There is a large variation in the estimated effects of monetary policies on output and prices. We find that the use of different econometric methodologies is an important variable explaining these differences. In addition, we analyze the importance of macroeconomic variables. Thus we find that in countries with high inflation, the output effects of monetary policies are significantly reduced. A lot of variation in the estimated effects of monetary policies remains unexplained. More research will have to be done to understand these large differences.
\end{abstract}

JEL Classification: E4, E5, E6.

\author{
Paul De Grauwe \\ Katholieke Universiteit Leuven \\ Center for Economic Studies \\ Naamsestraat 69 \\ 3000 Leuven \\ Belgium \\ paul.degrauwe@econ.kuleuen.ac.be
}

\author{
Cláudia Costa Storti \\ Banco de Portugal \\ R.D. Estefania No. 193 Dto \\ 1000-155 Lisboa \\ Portugal \\ cstorti.@bportugal.pt
}

We are grateful to Laura Rinaldi for research assistance. We also gratefully acknowledge the comments and criticisms of Giorgio Bellettini and the participants of the Conference. 


\section{Introduction}

The econometric analysis of the effect of monetary policies has changed considerably during the 1990s mainly as a result of the advance of econometric techniques, and in particular as a result of the increasing use of VAR and SVAR techniques. This has led to a proliferation of the econometric evaluation of the effectiveness of monetary policies in many countries.

A characteristic of these studies is the large variance in the results, i.e. in some countries and/or during particular sample periods, the estimated effects of monetary policy shocks on output and prices appear to be strong, in other countries and/or sample periods these effects appear to be weak.

The purpose of this paper is to systematically evaluate these empirical studies using a "meta-analysis". This technique is frequently used in medical sciences and has sporadically been used in economics (see e.g. Rose(2004), Knell and Stix(2003), Nijkamp and Poot(2004)) ${ }^{1}$. The ultimate objective of this analysis is to find the factors that can explain the large variation in the estimated effects of monetary policy shocks on output and the price level.

The way will proceed is to first collect data on the parameters that measure the effect of monetary policy on output and prices. We will distinguish between the short-term effects and the long-term effects on output and price levels. The parameters collected from these studies will then be used as the dependent variable in an econometric analysis that aims at explaining the variation in these parameters.

\section{The data}

The source of the data we use are the empirical papers on the effects of monetary policies. We restricted the empirical papers to those published after 1990. The main reason is that during the 1990s the new econometric technology using VARs came into use in studies evaluating monetary policies. Since this has become the new stateof-the-art econometric technology we decided to restrict the analysis to a period in which this technology was introduced.

\footnotetext{
${ }^{1}$ See Stanley(2001) for a critical analysis of the use of meta-analysis in economics.
} 
We used a search of Econlit and also searched in well-known discussion paper series (NBER, CEPR, CESifo) and the discussion paper series of central banks. We obtained 43 studies that report numbers on the effect of monetary policy. There are of course many more papers that analyse the transmission of monetary policies, but many of these papers provide no or incomplete quantitative evidence of the effects of monetary policy, or report results that cannot be made comparable to other results.

We were interested in four different parameters measuring the effect of monetary policy. These are

- The short-term effect on output

- The long-term effect on output

- The short-term effect on the price level

- The long-term effect on the price level

We decided that the effects after one year measure the short-run, while the effects obtained after five years measure the long run. We would have liked to use a longer time span. However, very few studies report effects after five years. In some studies the longest time span is even shorter than five years.

The way the empirical results are reported is far from harmonized. The VAR and SVAR studies report impulse response functions that measure the impact of a monetary policy shock (typically a short-term interest rate) on output and prices. We harmonized these numbers so that each number measures the effect of a $1 \%$ increase of the interest rate on output and the price level at the respective horizons ${ }^{2}$.

There are very few studies that use the money stock as the policy variable. Almost no VAR or SVAR studies use the money stock. As a result, we restrict the analysis to those studies that use the interest rate as the policy variable.

There are also a number of studies using structural econometric models. These studies typically report the effect of a monetary policy shock on output (prices) as the difference between the simulated output (price) level obtained with and without the policy shock. We used these numbers and applied the same harmonization so that

\footnotetext{
${ }^{2}$ Many VAR and SVAR studies only report the graphs of the impulse response functions. We therefore enlarged these graphs considerably allowing us to measure the coefficients of the impulse response functions with great precision.
} 
these parameters measure the effect of a shock in the interest rate (money stock) of $1 \%$.

Many of the 43 studies selected report results for more than one country. As a result we obtained 144 parameters measuring the short-term and long term output effects of monetary policy shocks. For the effects of monetary policy on the price level we only obtain 122 parameters because a number of studies focus only on the output effects of monetary policy.

\section{Some descriptive statistics}

Before engaging in the econometric analysis it is useful to present some descriptive statistics of the different parameters measuring the effects of monetary policies. We do this in the form of histograms. We first concentrate on the output effects. In figures 1 and 2 we show the histogram of the short-term and long-term effects of an interest rate increase of $1 \%$. We eliminated some outliers, i.e. in the case of the short-term effects all the coefficients lower than -2 , and in the case of the long-term effects all the coefficients lower than -1 . However, for the sake of completeness we present the full sample in appendix.

From figure 1 we learn that the mean effect of the monetary policy shock is -0.33 , i.e. on average an increase of the interest rate of $1 \%$ leads after one year to a decline in output by $0.33 \%$. The long-term effect (figure 2 ) is on average -0.16 . A simple test of the significance of these averages reveals that both coefficients are statistically different from zero. For the short-term coefficient we find a t-ratio of -10.9 and for the long-term coefficient a t-ratio of -6.5 . This is a little troublesome for the longterm coefficient because it implies that the one percent interest rate increase has a significant effect on output 5 years later. We will come back to this feature in the econometric analysis.

We also note that the distribution of the parameters is not normally distributed. This can be seen from the Jarque-Bera statistic. We observe that the distribution is not symmetric which can be seen from the fact that the mean and the median differ substantially. In particular we find that the mean is smaller than the median, which results from the fact that the mean is very much influenced by outliers. 
From figures 1 and 2 we also learn that there is a wide variation in the reported coefficients. The main purpose of the econometric analysis will be to explain this wide variation.

Figure 1: Histogram of short-term output effect of an increase in the interest rate by one percentage point

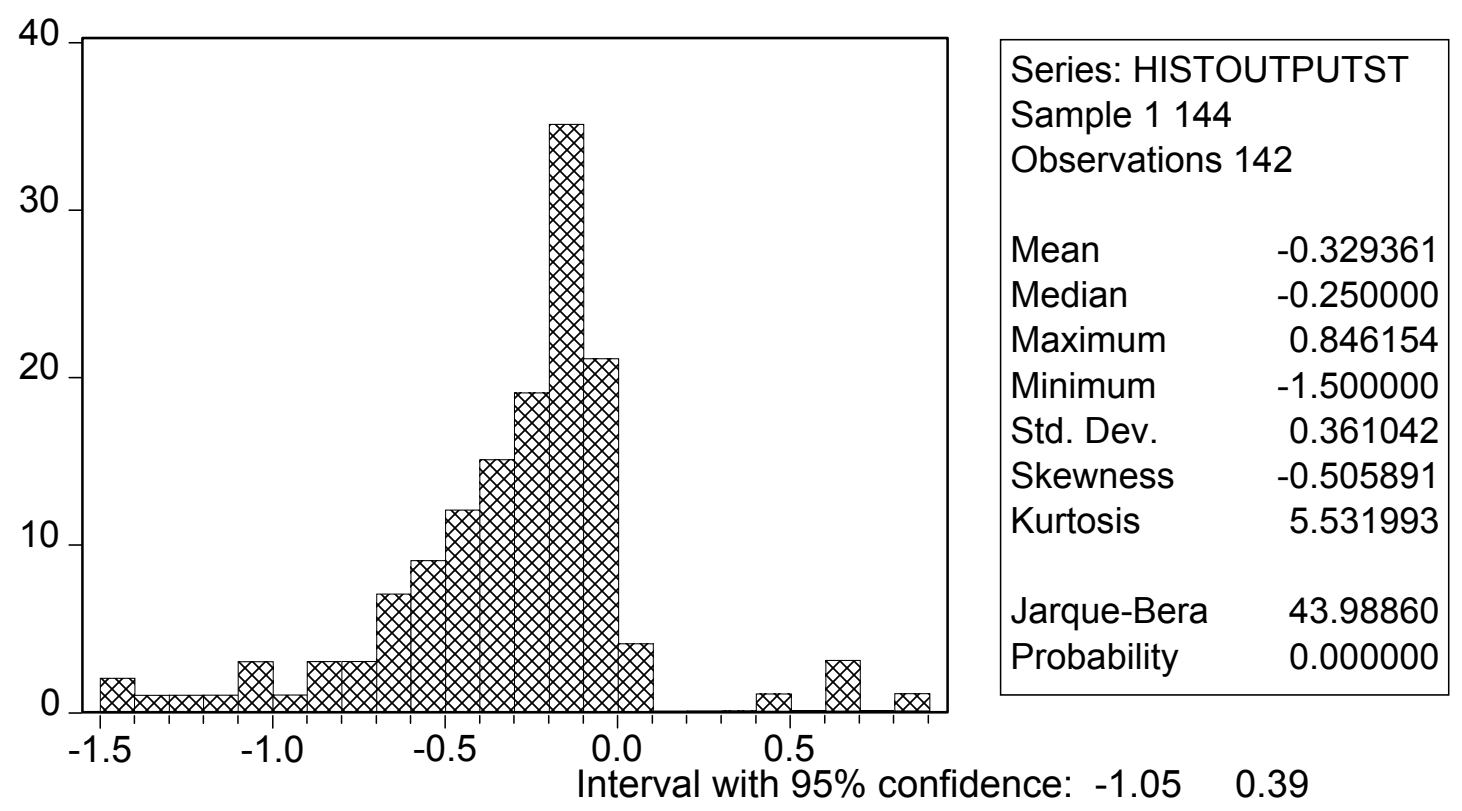

Figure 2: Histogram of long-term output effect of an increase in the interest rate by one percentage point

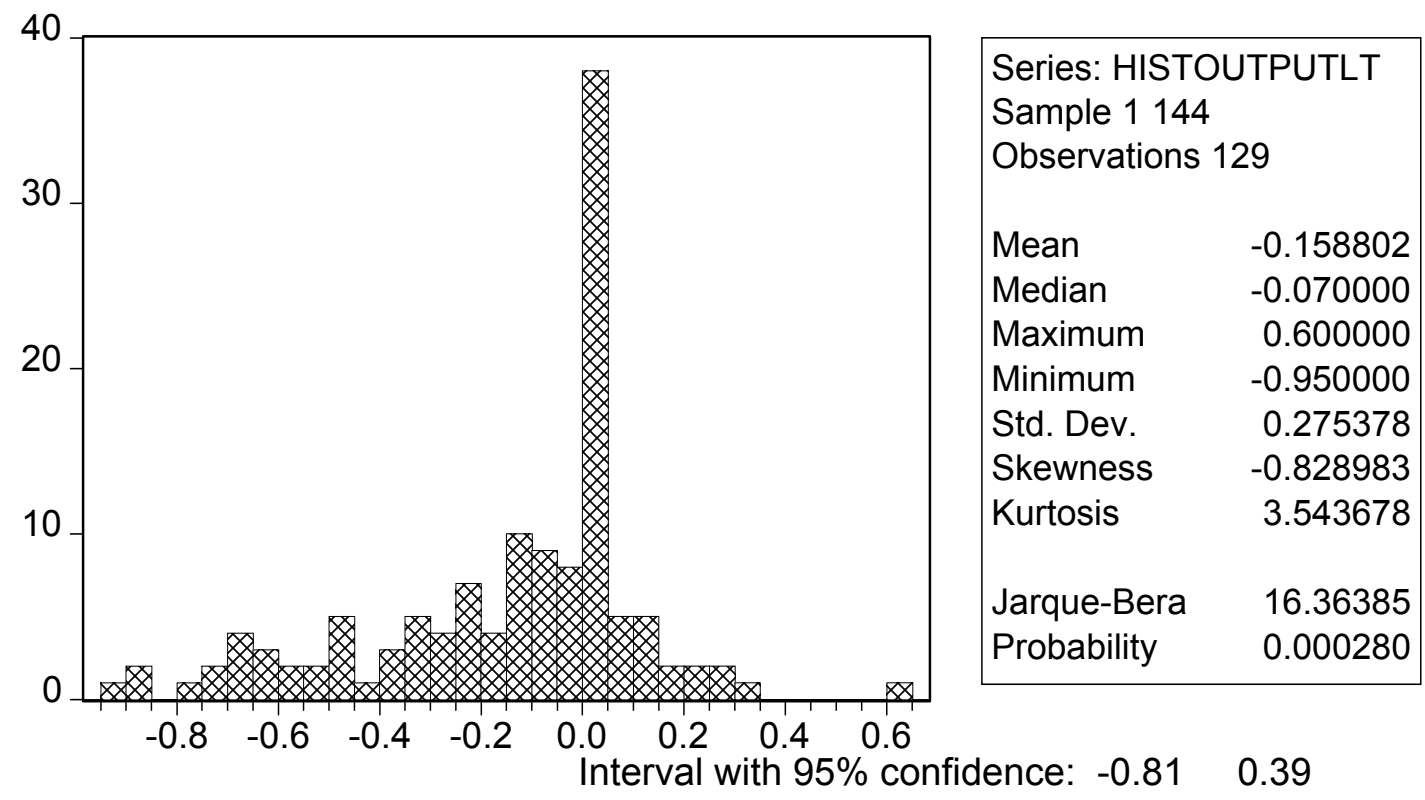

We perform a similar exercise with the short-term and the long-term effects on the price level. We show the results in figures 3 and 4 . We find that on average the short- 
term price effects of an increase in the interest rate by $1 \%$ are very small, i.e. -0.07 . A simple t-test of the significance of this average effect reveals that it is statistically different from zero (t-ratio=3.1). The long-term price effect (figure 4) is significantly larger (in absolute value) than the short-term effect. The average effect is found to be -0.22 , and is statistically significantly different from zero. As in the case of the output effects we find that the reported coefficients show a wide variation.

Figure 3: Histogram of short-term price effect of an increase in the interest rate by one percentage point

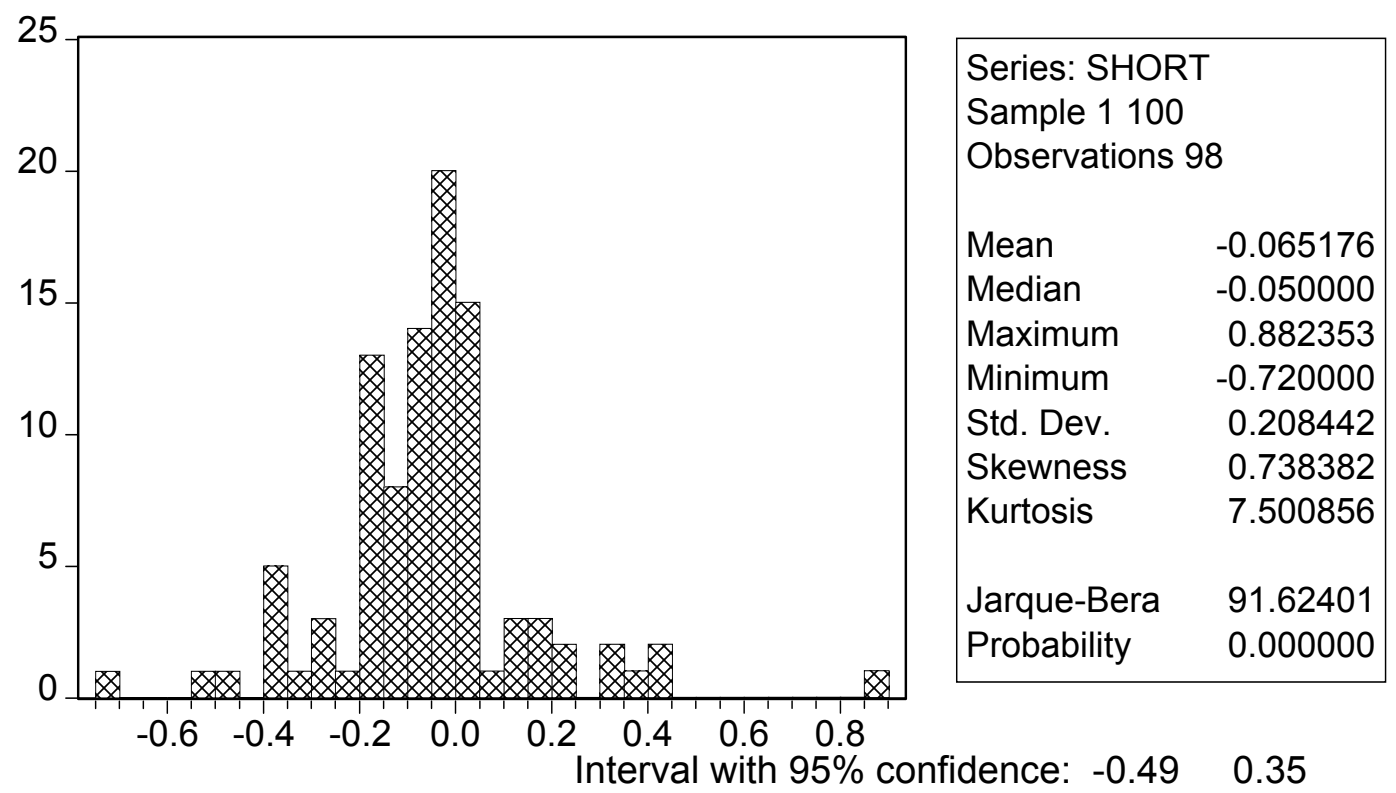

Figure 4: Histogram of long-term price effect of an increase in the interest rate by one percentage point

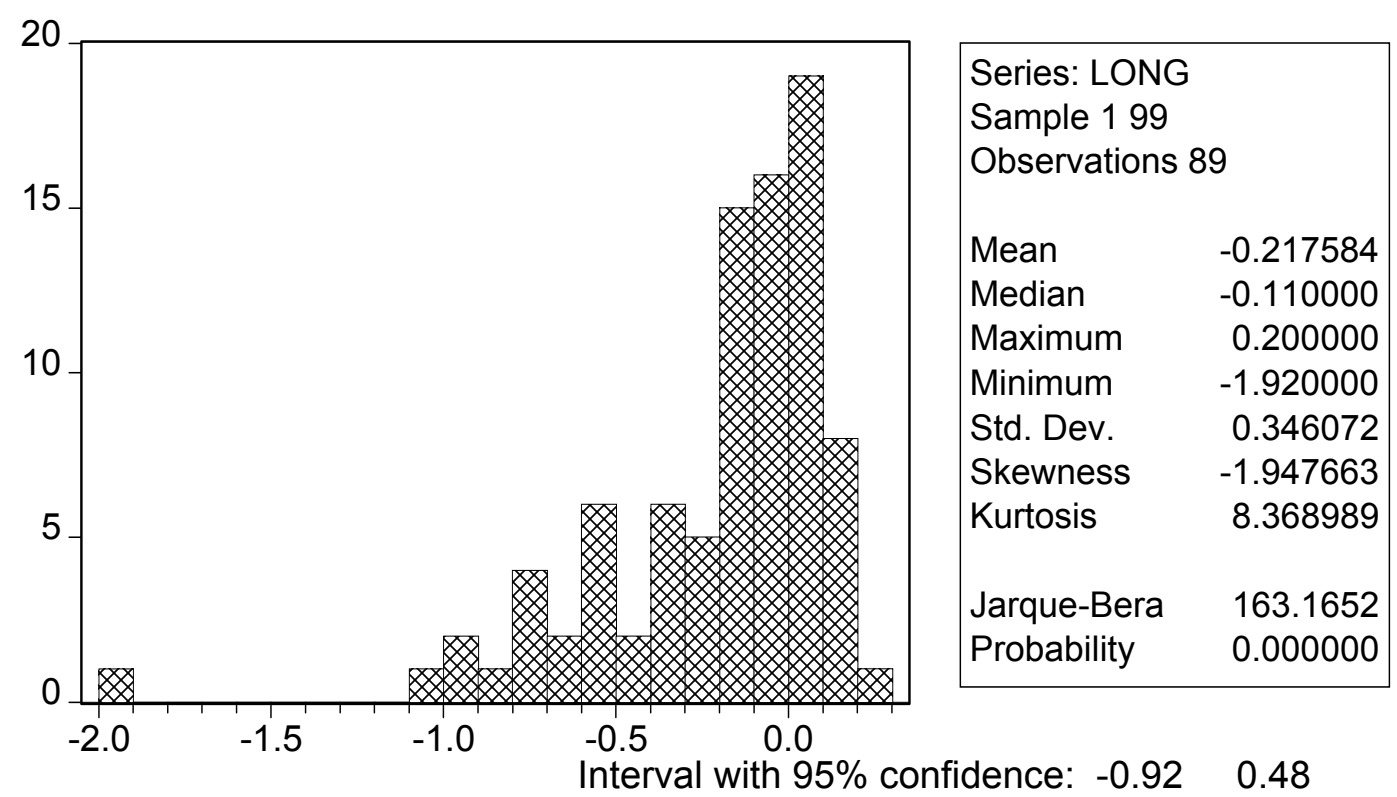


From this descriptive analysis we conclude the following. First, the simple averages of the reported coefficients confirm much of the consensus theory about the effects of monetary policy. This is that the short-term output effect is relatively strong but tends to weaken over longer time horizons. The opposite holds for the price effect: this is weak in the short run but significantly larger in the long-run. We notice one puzzle (to which we will return): contrary to what the theory predicts, the "long-run" (five year) output effect is not zero. It remains significantly different from zero. A more elaborate econometric analysis will have to be performed to find out whether this result is robust, and if so, how it can be explained.

A second conclusion of the descriptive analysis is that there is a large variation in the reported parameters. This lack of precision is problematic because it reduces the usefulness of the empirical estimates for the monetary authorities. To give an example, the short-term effect of an increase in the interest rate is found to be on average -0.33 (and statistically different from zero). Yet this average effect is not very representative for the sample: $21 \%$ of the observed coefficients are zero or positive, while $22 \%$ are equal or smaller than -0.5 . The purpose of the econometric analysis is to better understand the factors that explain this wide variation. This can help us to improve the precision of our knowledge about the effects of monetary policy.

\section{Econometric analysis: output effects}

In this section we specify an econometric equation explaining the explaining the different parameters described in the previous section. We introduce two types of explanatory variables. One type of variables describes the characteristics of the different studies. The second type of explanatory variables are macroeconomic and describes the nature of the macroeconomic regime of the countries involved in the empirical studies.

The econometric equation is specified as follows:

$$
\begin{aligned}
& \mathrm{PS}_{\mathrm{i}}=\mathrm{a}+\Sigma_{\mathrm{k}} \beta_{\mathrm{k}} \mathrm{D}_{\mathrm{k}}+\Sigma_{\mathrm{j}} \gamma_{\mathrm{j}} \mathrm{M}_{\mathrm{j}}+\varepsilon_{\mathrm{i}} \\
& \mathrm{PL}_{\mathrm{i}}=\mathrm{c}+\Sigma_{\mathrm{k}} \eta_{\mathrm{k}} \mathrm{D}_{\mathrm{k}}+\Sigma_{\mathrm{j}} \varphi_{\mathrm{j}} \mathrm{M}_{\mathrm{j}}+\omega_{\mathrm{i}}
\end{aligned}
$$


where $\mathrm{PS}_{\mathrm{i}}$ and $\mathrm{PL}_{\mathrm{i}}$ are the observed short-term and long term parameters measuring the effect of monetary policy.

The variables $D_{k}$ are dummy variables expressing a particular characteristic of the study from which parameter i was obtained. We distinguish between the following characteristics:

- the countries analysed in the study: in this case each country is represented by a separate dummy variable

- the econometric technique used. We distinguish between three types of econometric methods. The first one uses plain VARs, i.e. the method used to impose identifying restrictions is based on imposing a recursiveness ordering (Choleski decomposition). The second one uses SVARS. This is a VAR method that relies on an economic theory to impose prior restrictions on (some) parameters of the model. Quite often, this method imposes a restriction on the long-term effect of monetary policy (e.g. a zero restriction on the longterm output effect). Finally the third technique relies on traditional econometric modelling.

- The variable used to measure output. We distinguish between GDP, industrial production (PROD), and output gap (GAP). Each of these measures is represented by a separate dummy.

- The sample period during which the studies were performed. We distinguish between studies in which the sample period starts in the sixties, the seventies and the eighties. This distinction is introduced to find out whether the coefficients measuring the effectiveness of monetary policy have changed over time. We introduce three dummy variables: SIXTIES, SEVENTIES, EIGHTIES.

- The publication date of the studies. Since the empirical studies analysed here were published in 1990 or later, we use a time variable defined as: 1, 2, 3, . . 12. The variable is called PUBDATE.

The variables $\mathrm{M}_{\mathrm{j}}$ are macroeconomic variables associated with country $\mathrm{i}$ (that is represented by parameter i). We use the following variables: 
- The openness of the country involved, as measured by the ratio of its exports to its GDP. We expect that the output effects of domestic monetary policy shocks are smaller in relatively open countries than in relatively closed ones.

- The size of countries as measured by their GDP in dollars.

- The exchange rate regime. We distinguished between two exchange rate regimes, fixed and flexible. The countries on a flexible exchange rate regime are the UK, the US, Japan and Germany. The others (EMS countries and emerging countries) were on a fixed exchange rate regime ${ }^{3}$.

- The rate of inflation that prevailed on average during the sample period over which the output coefficient was estimated. There is a theoretical presumption that the effect of a monetary expansion on output declines with the level of inflation. Several theoretical models can be invoked to substantiate this. The most influential is Lucas(1972) "island model". In this model, the aggregate supply equation depends on the relative variance of real and nominal disturbances. The implication is that in a regime of high nominal variability an increase in prices is more likely to be interpreted as resulting from an aggregate price increase than in a regime of low nominal variability. As a result, the real effects of such an increase in prices will be reduced. A similar analysis can be performed using the Philips curve as a tool. In such a framework, the Philips curve is also non-linear in the rate of inflation. Thus, when inflation is high one will need a stronger monetary surprise to generate a given increase in output (decline in unemployment) than when inflation is low ${ }^{4}$. This proposition was also tested by Lucas(1973).

- The importance of the banking sector as measured by the ratio of the consolidated balance sheet of the banking sector over GDP. The theory is not clear about how this variable affects the output effects of monetary policy shocks. We introduce this variable here to find out whether differences in the size of the banking sector can explain the differences in the estimated output coefficients.

\footnotetext{
${ }^{3}$ One could clearly introduce finer distinctions between different exchange rate regimes. For example, one could use the IMF-classification of exchange rate regimes. This classification has been criticised, however. See Calvo and Reinhart(2000).

${ }^{4}$ See Wyplosz(2001).
} 
A final issue concerns the weights given to the different publications. The quality of the different studies is not the same. One would therefore like to adjust for the quality of the studies. It is, however, very difficult to do this without introducing subjective judgment. This could lead to the possibility of a selection bias, whereby the researcher gives a higher weight to those studies, which come close to his priors. We have not attempted to do this. The only quality criterion we have maintained is the length of the sample periods of the different studies ${ }^{5}$. Thus studies that use a longer sample period, and thus more information, receive a higher weight than studies using a shorter sample period. The way we do this is by weighting each study by the length of the sample period (expressed as a percent of the longest sample period). We will present results using both weighted and unweighted data.

In table 1 we present the results of estimating equation 1 (short-term coefficients). One problem of interpretation of the results of table 1 arises because of the fact that the country dummies are correlated with some of the macroeconomic variables, i.e. size, openness and inflation. We also found, however, that the differences in the country dummy coefficients are not statistically significant. This is shown in table 2 , which presents a Wald test of equality of the country coefficients. We observe that we cannot reject the null hypothesis that the country effects are equal.

\footnotetext{
${ }^{5}$ Another possible quality criterion could be the significance of the estimated coefficients. The trouble with this is that many studies do not report confidence levels of the estimated coefficients.
} 


\begin{tabular}{|c|c|c|}
\hline & unweighted data & weighted data \\
\hline \multirow{2}{*}{ AUSTRIA } & -1.073 & -1.017 \\
\hline & -2.207 & -1.672 \\
\hline \multirow[t]{2}{*}{ BELGIUM } & -0.766 & -0.726 \\
\hline & -1.504 & -1.205 \\
\hline \multirow[t]{2}{*}{ DENMARK } & -1.051 & -0.816 \\
\hline & -2.224 & -1.409 \\
\hline \multirow[t]{2}{*}{ EMERGING } & -0.678 & -0.621 \\
\hline & -1.011 & -0.715 \\
\hline \multirow[t]{2}{*}{ EUROZONE } & -1.374 & -1.599 \\
\hline & -2.507 & -2.373 \\
\hline \multirow[t]{2}{*}{ FINLAND } & -0.877 & -0.818 \\
\hline & -1.921 & -1.471 \\
\hline \multirow[t]{2}{*}{ FRANCE } & -1.142 & -1.085 \\
\hline & -2.47 & -1.839 \\
\hline \multirow[t]{2}{*}{ GERMANY } & -1.175 & -1.197 \\
\hline & -2.639 & -2.094 \\
\hline \multirow[t]{2}{*}{ GREECE } & -1.337 & -1.239 \\
\hline & -1.7 & -1.361 \\
\hline \multirow[t]{2}{*}{ IRELAND } & -0.929 & -0.846 \\
\hline & -1.716 & -1.256 \\
\hline \multirow[t]{2}{*}{ ITALY } & -1.104 & -1.049 \\
\hline & -2.008 & -1.464 \\
\hline \multirow[t]{2}{*}{ JAPAN } & -1.049 & -1.15 \\
\hline & -1.451 & -1.186 \\
\hline \multirow[t]{2}{*}{ LUXEMBOURG } & -2.394 & -2.678 \\
\hline & -1.633 & -1.268 \\
\hline \multirow[t]{2}{*}{ NETHERLANDS } & -1.053 & -0.947 \\
\hline & -2.157 & -1.568 \\
\hline \multirow[t]{2}{*}{ PORTUGAL } & -1.009 & -1.037 \\
\hline & -1.303 & -1.045 \\
\hline \multirow[t]{2}{*}{ SPAIN } & -0.98 & -0.967 \\
\hline & -1.655 & -1.249 \\
\hline \multirow[t]{2}{*}{ SWEDEN } & -1.048 & -1.01 \\
\hline & -1.966 & -1.555 \\
\hline \multirow[t]{2}{*}{ UK } & -0.861 & -0.92 \\
\hline & -1.71 & -1.473 \\
\hline \multirow[t]{2}{*}{ us } & -1.56 & -1.595 \\
\hline & -3.675 & -3.04 \\
\hline \multirow[t]{2}{*}{ SVAR } & -0.069 & 0.079 \\
\hline & -0.54 & 0.568 \\
\hline \multirow[t]{2}{*}{ ECON } & 0.038 & 0.101 \\
\hline & 0.351 & 0.97 \\
\hline \multirow[t]{2}{*}{ GAP } & -0.123 & -0.15 \\
\hline & -0.866 & -0.99 \\
\hline IND & 0.005 & -0.068 \\
\hline
\end{tabular}




\begin{tabular}{|l|cc|}
\hline \multirow{3}{*}{ OPEN } & 0.044 & -0.537 \\
SIZE & -0.151 & -0.111 \\
PUBDATE & -0.814 & -0.502 \\
& 0.0001 & 0.0002 \\
BANKING & 1.943 & 2.314 \\
& 0.047 & 0.033 \\
SEVENTIES & 2.236 & 1.566 \\
& 0.368 & 0.445 \\
EIGTHIES & 1.48 & 1.146 \\
& -0.075 & -0.15 \\
INFLATION & -0.461 & -0.933 \\
& -0.299 & -0.32 \\
R-squared & -1.623 & -1.604 \\
Adjusted R-squared & 0.015 & 0.015 \\
Mean dependent var & 0.424 & 0.327 \\
& & \\
\hline
\end{tabular}

Note: numbers in italic are t-ratios

\begin{tabular}{|c|c|c|c|}
\hline \multicolumn{4}{|c|}{$\begin{array}{l}\text { Table 2: Test of equality of short-term country effects } \\
\text { (Wald Test) }\end{array}$} \\
\hline F-statistic & & Probability & 0.988 \\
\hline Chi-square & 5.763 & Probability & 0.990 \\
\hline
\end{tabular}

Therefore we re-estimated equation (1) restricting the country coefficients to be equal. The results are shown in table 3 . The constant term in table 3 represents the effect of the omitted dummies. As is well known, such an omission is necessary to avoid linear dependence. The omitted dummies are VAR, GDP and SIXTIES. Thus the constant term measures the coefficient of studies using VAR methods, using GDP as the measure of output and using a sample period starting in the sixties. The most important results can be summarized as follows. First, the use of different statistical methodologies matters. In particular, studies using SVAR-methods produce significantly stronger output effects, on average. Second, the publication date has a significant effect on the estimated coefficients. In particular, more recent publications produce significantly lower short-term output effects. It is unclear whether this is due to the increasing sophistication of econometric techniques, or whether this is due to a possibly decreasing output effect of monetary policy over time. We can gain some 
insight on the latter issue by looking at the coefficients of the sample periods. It appears that studies that start the sample period in the eighties produce larger output coefficients (in absolute value) than studies that start the sample period earlier, suggesting that there is no evidence that the effectiveness of monetary policies has declined. The significance of this difference is not very strong, however. All this suggests that the declining output effects associated with publication dates could be due to the increased sophistication of econometric techniques.

A third interesting result relates to the effects of inflation. We find that inflation tends to reduce the output effect of monetary policy. For every percentage point increase in inflation the short-term output parameter declines (in absolute value) by approximately 0.04 . This effect is significant in the regression using unweighted data, but is less so in the regression using weighted data. This result is conform with economic theory.

\begin{tabular}{|c|c|c|c|c|}
\hline \multicolumn{5}{|c|}{$\begin{array}{c}\text { Table 3: Short-term output coefficients (equation (1)) } \\
\text { Included observations: } 127\end{array}$} \\
\hline \multirow[b]{2}{*}{ Variable } & \multicolumn{2}{|c|}{ Unweighted data } & \multicolumn{2}{|c|}{ Weighted data } \\
\hline & Coefficient & t-Statistic & Coefficient & t-Statistic \\
\hline $\mathrm{C}$ & -1.333 & -4.543 & -1.067 & -4.536 \\
\hline SVAR & -0.388 & -2.555 & -0.124 & -0.872 \\
\hline ECON & -0.125 & -0.841 & -0.012 & -0.104 \\
\hline IND & 0.140 & 0.967 & 0.061 & 0.469 \\
\hline GAP & -0.174 & -0.853 & -0.163 & -0.910 \\
\hline SEVENTIES & 0.066 & 0.415 & 0.058 & 0.470 \\
\hline EIGTHIES & -0.275 & -1.646 & -0.213 & -1.415 \\
\hline INFLATION & 0.038 & 1.895 & 0.023 & 1.372 \\
\hline FIX & 0.046 & 0.294 & 0.064 & 0.489 \\
\hline PUBDATE & 0.075 & 2.821 & 0.048 & 2.197 \\
\hline SIZE & $3.9 \mathrm{E}-05$ & 0.979 & $5.02 \mathrm{E}-05$ & 1.308 \\
\hline OPEN & 0.141 & 0.781 & 0.126 & 0.816 \\
\hline BANKING & 0.067 & 0.599 & 0.052 & 0.711 \\
\hline R-squared & \multicolumn{2}{|c|}{0.194} & \multicolumn{2}{|c|}{0.130} \\
\hline Adjusted R-squared & \multicolumn{2}{|c|}{0.117} & \multicolumn{2}{|c|}{0.046} \\
\hline Mean dependent var & \multicolumn{2}{|c|}{-0.394} & \multicolumn{2}{|c|}{-0.366} \\
\hline
\end{tabular}

It is interesting to have an insight in the quantitative importance of the effect of inflation. The median inflation rate in the sample is 5.2\%. (In appendix we show the distribution of the inflation rates in the sample of countries) Thus for the median inflation rate the output coefficient is reduced by 0.2 . For the highest inflation country 
in the sample (16\%) the output coefficient is reduced by 0.622 . Thus the output effect is reduced by half compared to the benchmark in the highest inflation country.

The other variables in the regression equation do not have a significant effect on the output coefficients. In particular, the different measures of output do not produce significantly different coefficients. Similarly, the macroeconomic variables such as openness, size of the countries and the importance of the banking sector do not create significant differences in the output effects of monetary policy shocks. This may seem surprising. For example, one may expect that openness and size matter. In particular, the output effects of monetary policies should be smaller in relatively small and open economies because much of the domestically generated monetary shocks spill over to the rest of the world. However, in small open economies most of the monetary policy shocks are not generated by domestic monetary authorities. They are typically the result of monetary policy shocks originating in large countries. To give an example. When the German Bundesbank increased its interest rate, central banks of countries like the Netherlands and Belgium routinely increased their short-term interest rates a few minutes later. As a result, the monetary policy shock occurred in many countries at the same time. It is therefore not so surprising that monetary policy shocks can have similar effects in large and small countries.

The results of estimating the long-run effects of monetary policy shocks (equation (2)) are presented in table 4 (see appendix). As in the case of the short-term effect we find that the country coefficients are not significantly different. We, therefore, restricted the country effects to be equal ${ }^{6}$. The results are shown in table 5 and can be interpreted as follows. First, the long-term output coefficient of the benchmark case (use of VAR, GDP, estimated since the sixties), as measured by the constant, is statistically different from zero. It is also rather large in absolute value. This means that after five years monetary policy shocks continue have a strong output effect in the benchmark case. We also observe that the use of different econometric techniques has a strong and significant effect. In particular, studies using SVAR-techniques or traditional econometrics reduce the long-term output effect by about half compared to studies using VAR. The reason for these strong differences is that typically SVARs and traditional econometric techniques add constraints on the long-term output effects

\footnotetext{
${ }^{6}$ A Wald test of equality of the country coefficients could not reject the hypothesis that these coefficients are equal.
} 
of monetary policies. These constraints are absent from VARs. This result is troublesome because it suggests that studies that use economic theory to impose constraints on coefficients lead to significantly different results than those studies that let the "data talk".

As in the case of the short-term output coefficients we find that inflation is an important variable. It has a significant effect at the 5\% level in the unweighted regression and at the $10 \%$ level in the weighted regression. In addition, the quantitative importance of this variable is high. In particular, we find that for the median inflation country the long-term output coefficient is reduced by 0.21 while for the highest inflation country it is reduced by 0.64 . As a result, for the highest inflation countries in the sample the long-term output effects of monetary policies are close to zero. The interesting aspect of this result is that for the low inflation countries, these long term output effects are strong and significant.

The other macroeconomic variables do not have significant effects on the long-term output coefficients. In contrast with the short-term coefficients we do not find that publication date or the sample period affects the long-term coefficients.

\begin{tabular}{|c|c|c|c|c|}
\hline \multicolumn{5}{|c|}{$\begin{array}{c}\text { Table 5: Long-term output coefficients (equation (2)) } \\
\text { Included observations: } 122\end{array}$} \\
\hline & \multicolumn{2}{|c|}{ Unweighted data } & \multicolumn{2}{|c|}{ Weighted data } \\
\hline Variable & Coefficient & $\mathrm{t}$-Statistic & Coefficient & t-Statistic \\
\hline$\overline{\mathrm{C}}$ & -0.769 & -2.689 & $\begin{array}{c}-0.848 \\
\end{array}$ & -2.528 \\
\hline SVAR & 0.282 & 1.829 & 0.411 & 1.977 \\
\hline ECON & 0.378 & 2.413 & 0.500 & 2.882 \\
\hline IND & 0.208 & 1.390 & 0.210 & 1.087 \\
\hline GAP & 0.467 & 2.341 & 0.560 & 2.182 \\
\hline SEVENTIES & -0.140 & -0.879 & -0.260 & -1.432 \\
\hline EIGTHIES & 0.152 & 0.901 & 0.118 & 0.538 \\
\hline INFLATION & 0.039 & 1.909 & 0.038 & 1.597 \\
\hline FIX & 0.228 & 1.447 & 0.273 & 1.446 \\
\hline PUBDATE & -0.007 & -0.301 & -0.009 & -0.309 \\
\hline SIZE & $4.73 \mathrm{E}-05$ & 1.191 & $5.10 \mathrm{E}-05$ & 0.927 \\
\hline OPEN & 0.198 & 1.103 & 0.283 & 1.263 \\
\hline BANKING & -0.023 & -0.213 & -0.005 & -0.051 \\
\hline uared & \multicolumn{2}{|c|}{0.192} & \multicolumn{2}{|c|}{0.256} \\
\hline Adjusted R-squared & \multicolumn{2}{|c|}{0.111} & \multicolumn{2}{|c|}{0.181} \\
\hline Mean dependent var & \multicolumn{2}{|c|}{-0.252} & \multicolumn{2}{|c|}{-0.304} \\
\hline
\end{tabular}




\section{Is US monetary policy more effective than Eurozone monetary policies?}

It is often asserted that monetary policies in the US are more effective in influencing output than monetary policies in the Eurozone. The reason for this difference in effectiveness is often seen in the difference in supply rigidities between the US and the Eurozone countries. More specifically, the US economy is seen to be more flexible than the Eurozone economies. As a result, a given monetary policy stimulus leads to a larger output response in the US than in Europe ${ }^{7}$. This argument is often used to explain why the ECB is more reluctant to stimulate the economy. In this view the structural rigidities in the Eurozone economies prevent stimulatory monetary policies from expanding output.

Our previous tests of equality of the country coefficients casts some doubts about this view. But these tests were tests of equality of all country coefficients. We need to test more specifically whether the estimated output effects obtained in the US studies differ significantly from those obtained in the Eurozone countries. In order to do so, we performed a Wald-test. Our null hypothesis is that the output coefficients of the US and of the Eurozone countries are equal. We show the result of this test in table 5 for the short-term parameters and in table 6 for the long-term parameters. We find that the null of equality of the short-term coefficients cannot be rejected with a probability of more than $99 \%$. The results for the long-term coefficients are not as conclusive, i.e. we cannot reject equality with a probability of approximately $10 \%$. It should be stressed though that the long-term Eurozone coefficients tend to be larger in absolute value than the US coefficients, suggesting that if we reject equality, the Eurozone coefficients are larger in absolute value than the US coefficients. We conclude that the evidence that the US monetary policy is more effective in influencing output than the Eurozone monetary policy is not corroborated by the existing empirical studies.

\begin{tabular}{|llll|}
\hline $\begin{array}{c}\text { Table 5: Test of equality short-term output } \\
\text { parameters of US and Euro-countries } \\
\text { (Wald test) Table 11 }\end{array}$ & \\
\hline F-statistic & 0.246 & Probability & 0.995 \\
Chi-square & 2.952 & Probability & 0.996 \\
\hline
\end{tabular}

\footnotetext{
${ }^{7}$ In a recent Angeloni, et al.(2003) find such a difference which they interpret to be the result of a difference in the effect of interest rate changes on consumption in the US and in the Eurozone.
} 


\begin{tabular}{|llll|}
\hline $\begin{array}{c}\text { Table 6: Test of equality long-term output } \\
\text { parameters of US and Euro-countries } \\
\text { (Wald test) }\end{array}$ Table 12 & & \\
\hline F-statistic & 1.629 & Probability & 0.097 \\
Chi-square & 19.55 & Probability & 0.076 \\
\hline
\end{tabular}

\section{Econometric Analysis: price effects}

In this section we analyse the short-term and long-term price effects of monetary policies. As will be remembered from section 3 we found a wide variation of the parameters measuring these short-term and long-term price effects. We will proceed in the same way as in the previous section. We estimate the econometric model consisting of equations (1) and (2), where $\mathrm{PS}_{\mathrm{i}}$ and $\mathrm{PL}_{\mathrm{i}}$ now represent the estimated short-term and long-term price effects of monetary policy shocks. A note of warning is necessary here. Because not all the empirical studies of the effect of monetary policies report results of the effects on the price level, we have fewer data points in the sample (101). As a result, the statistical quality of the econometric results is weaker than in the previous section.

We first concentrate on the short-term price effects (equation (1)). The estimation results are shown in table 7 (see appendix). As before, we also estimate the model under the restriction that the country coefficients are equal. The results of this estimation are presented in table 8 .

A number of results are worth stressing. First, the use of different econometric techniques matters. In the benchmark case (VAR) we obtain a positive coefficient, although it is not significantly so. The use of SVAR, however, leads to a price coefficient which is significantly different from the VAR and which is approximately zero $^{8}$. These results are consistent with the often noted "price puzzle" indicating that an increase in the interest rate leads to an increase in the price level. This puzzle arises mainly with the use of VARs and tends to disappear with the use of SVARs. It is also worth noting that in more recent studies the price puzzle disappears. This can be seen from the coefficient of PUBDATE, which is negative, and significant at the $10 \%$ level. Since the PUBDATE variable varies from 1 to 12 , it can be seen that in the most recent publications the price puzzle seems to have disappeared completely.

\footnotetext{
${ }^{8}$ Note that to obtain the average coefficient of studies using SVAR we have to subtract the estimated SVAR-coefficient from the constant.
} 
Thus, over the years researchers have tried to correct for the anomalous price puzzle results, so that at the end of the 1990s it had all but disappeared from the econometric studies.

A second interesting result relates to the effect of different exchange rate regimes. It appears that countries that fixed their exchange rates (mainly EMS-countries) may have experienced stronger "price puzzles" than floating exchange rate countries (US, UK, Japan). The significance of this difference between exchange rate regimes, however, is limited so that it is unclear whether great importance can be attached to this result.

On the whole it appears to be difficult to explain the large differences in the shortterm price effects of monetary policy shocks. Our model can explain only 10 to $20 \%$ of the total variation of these price effects. If we include the country effects, however, the model explains 20 to $30 \%$ of the total variation (see table 7 in appendix).

\begin{tabular}{|c|c|c|c|c|}
\hline \multicolumn{5}{|c|}{$\begin{array}{c}\text { Table 8: Short-term price coefficients (equation (1)) } \\
\text { Included observations: } 86\end{array}$} \\
\hline \multirow[b]{2}{*}{ Variable } & \multicolumn{2}{|c|}{ Unweighted data } & \multicolumn{2}{|c|}{ Weighted data } \\
\hline & Coefficient & $\mathrm{t}$-Statistic & Coefficient & t-Statistic \\
\hline $\mathrm{C}$ & 0.216 & 0.942 & 0.219 & 1.047 \\
\hline SVAR & -0.257 & -2.658 & -0.364 & -3.224 \\
\hline ECON & -0.089 & -0.767 & -0.114 & -0.989 \\
\hline INFLATION & -0.022 & -1.276 & -0.025 & -1.395 \\
\hline SIZE & $4.03 \mathrm{E}-06$ & 0.120 & $3.46 \mathrm{E}-05$ & 0.893 \\
\hline OPEN & -0.018 & -0.145 & -0.051 & -0.366 \\
\hline BANKING & 0.050 & 0.642 & 0.064 & 0.997 \\
\hline PUBDATE & -0.021 & -1.247 & -0.028 & -1.662 \\
\hline FIX & 0.134 & 1.159 & 0.256 & 1.984 \\
\hline R-squared & \multicolumn{2}{|c|}{0.116} & \multicolumn{2}{|c|}{0.201} \\
\hline Adjusted R-squared & \multicolumn{2}{|c|}{0.024} & \multicolumn{2}{|c|}{0.117} \\
\hline Mean dependent var & \multicolumn{2}{|c|}{-0.098} & \multicolumn{2}{|c|}{-0.096} \\
\hline
\end{tabular}

The results of estimating equation (2), which explains the variation in the long-term price effects, are shown in table 9, when we include the country effects (see appendix) and in table 10 when we restrict the country effects to be equal. The model with the country effects is capable of explaining about $50 \%$ of the total variation of the longterm price effects. 
We also obtain a number of interesting results. First, the use of VARs and SVARs produces long-term price effects that are close to -1 . This is a much stronger effect than the one obtained with the use of traditional econometric methods (ECON).

Second, the long-term price effects obtained in studies whose sample period started in the 1970s appears to be significantly stronger than in other decades. Whether this is due to the fact that this was a decade characterised by high inflation is unclear, since the inflation variable, which measures the effect of inflation, is not significant.

Third, the exchange rate regime appears to matter. In countries on a fixed exchange rate the long-term price coefficient is much smaller (in absolute value) than the benchmark flexible exchange rate case. This seems to suggest that in countries with a fixed exchange rate a monetary policy shock spills over to the rest of the world leaving the price level relatively unaffected in the long run. In contrast, in flexible exchange rate countries the long-term price effect of a monetary policy shock is reinforced by the exchange rate change.

\begin{tabular}{|c|c|c|c|c|}
\hline \multicolumn{5}{|c|}{$\begin{array}{l}\text { Table 10: Long-term price coefficients (equation (2)) } \\
\text { Included observations: } 84\end{array}$} \\
\hline & \multicolumn{2}{|c|}{ Unweighted data } & \multicolumn{2}{|c|}{ Weighted data } \\
\hline Variable & Coefficient & $\mathrm{t}$-Statistic & Coefficient & t-Statistic \\
\hline $\mathrm{C}$ & -1.230 & -1.989 & -1.154 & -1.887 \\
\hline SVAR & 0.320 & 1.156 & 0.292 & 0.851 \\
\hline ECON & 0.640 & 1.814 & 0.908 & 2.453 \\
\hline INFLATION & 0.010 & 0.211 & 0.005 & 0.095 \\
\hline SIZE & 0.0001 & 1.281 & 0.0001 & 1.172 \\
\hline OPEN & 0.216 & 0.621 & 0.342 & 0.814 \\
\hline BANKING & 0.034 & 0.164 & 0.014 & 0.075 \\
\hline PUBDATE & 0.022 & 0.433 & 0.005 & 0.104 \\
\hline FIX & 0.624 & 1.795 & 0.589 & 1.449 \\
\hline SEVENTIES & -0.829 & -2.182 & -0.996 & -2.593 \\
\hline EIGHTIES & -0.013 & -0.034 & 0.015 & 0.035 \\
\hline R-squared & \multicolumn{2}{|c|}{0.195} & \multicolumn{2}{|c|}{0.261} \\
\hline Adjusted R-squared & \multicolumn{2}{|c|}{0.085} & \multicolumn{2}{|c|}{0.160} \\
\hline Mean dependent var & \multicolumn{2}{|c|}{-0.403} & \multicolumn{2}{|c|}{-0.493} \\
\hline
\end{tabular}

In the previous section we raised the issue of whether there is a significant difference in the output effects of monetary policies in the US and the Eurozone. We tested the hypothesis that monetary policies in a country with more flexible supply conditions (the US) have more effect on output than in countries with less flexible supply 
conditions (the Eurozone countries). The corollary of this hypothesis is that monetary policies in less flexible economies (Eurozone) have a stronger price effect than monetary policies in more flexible economies (the US). We tested this hypothesis using the estimated short- and long run price effects of tables 7 and 9. The results are shown in tables 11 and 12. We find that the estimated price coefficients are not significantly different between the US and the Eurozone countries.

\begin{tabular}{|llll|}
\hline \multicolumn{4}{|l|}{ Table 11: Test of equality short-term price } \\
parameters & (Wald test) & Table 19 & \\
\hline & & & \\
F-statistic & 0.296 & Probability & 0.984 \\
Chi-square & 3.262 & Probability & 0.986 \\
\hline
\end{tabular}

\begin{tabular}{|lrrr|}
\hline $\begin{array}{l}\text { Table 12: Test of equality long-term price } \\
\text { parameters }\end{array}$ & (Wald test) & Table 20 \\
\hline & & & \\
\hline F-statistic & 0.311 & Probability & 0.981 \\
Chi-square & 3.429 & Probability & 0.983 \\
\hline
\end{tabular}

\section{Conclusion}

In this paper we have performed a meta-analysis of the effects of monetary policies on output and prices. We can summarize the main results concerning the output effects of monetary policy as follows. First, there is a large variation in the reported output effects of monetary policies. This is the case both with the short-term and the longterm effects. Second, we are able to explain part of these large variations by a number of variables, although much remains unexplained. Third, a significant part of the wide variation in the long-term output effects is due to the use of different econometric techniques. In particular, the use of VARs produces long-term effects of monetary policies, while the use of SVARs and traditional econometric models leads to significantly lower long-term effects. This suggests that techniques that use economic theory to constrain parameters lead to significantly different effects than those techniques that "allow the data to speak".

Fourth, the theoretical presumption that the level of inflation affects the effectiveness of monetary policies was corroborated. More particularly, we found that in the countries, which experienced low inflation, the output effects of monetary policy 
shocks are substantial. This is the case both for the short-term and the long-term effects. In the high inflation countries of our sample, these output effects are much smaller. Moreover the long-term output effects of monetary policies all but vanish for the highest inflation countries. This confirms the theory, which suggests that in a low inflation environment monetary policies are quite effective in influencing output, both in the short-run and in the long run (five years or more). These effects tend to disappear when inflation increases..

Fifth, we could not find any significant differences in the output and price effects of monetary policies in the US and in the Eurozone countries. There is a popular view according to which monetary policies in the Eurozone are ineffective in boosting output because supply rigidities quickly lead to higher inflation while in the US monetary policies are capable of boosting output without strong inflationary effects. The existing econometric estimates of the output and price effects of monetary policies in the US and the Eurozone countries do not allow us to draw such a conclusion.

We also analysed the price effects of monetary policies. Our main results can be summarised as follows. First, the use of different econometric techniques matters. In particular, the use of VARs tends to produce a "price puzzle", i.e. a monetary contraction leads to an increase in the price level in the short-run. This effect is absent with the use of other econometric methods. We also found that the "price puzzle" disappears in econometric studies with a more recent publication date, suggesting that researchers have made efforts to purge this puzzle from their analysis.

The use of different econometric techniques also matters for the long-term price effects. We found that studies that use VAR and SVARs produce significantly larger long-term price effects than studies using traditional econometric techniques.

We also found that the exchange rate regime matters for the long-term price effects of monetary policies. In particular, monetary policy shocks in countries on a fixed exchange rate regime have a less pronounced effect on the price level in the long run, suggesting that in a fixed exchange rate regime, a large part of these monetary policy shocks spills over to the rest of the world.

Finally, we could not find any evidence that the price effects of monetary policy shocks in the US and in the Eurozone are different. Thus, the view that because of 
rigidities, monetary policy shocks in the Eurozone have a less pronounced effect on output and thus a more pronounced impact on prices is not corroborated by the existing econometric studies.

The research reported in this paper is still in a preliminary stage. Although we were successful in explaining part of the large variation in the empirical estimates of monetary policy shocks, much remains unexplained. More research will have to be done to increase our understanding of why the empirical estimates of the effects of monetary policies is so imprecise. 


\section{References}

Angeloni, I., Kashyap, A., Mojon, B., Terlizzese, D. , (2003), The Output Composition Puzzle: A Difference in the Monetary Transmission Mechanism in the Euro Area en the US, European Central Bank, Working Paper, no. 268, September.

Christiano, L., Eichenbaum, M., Evans, C., (1998), Monetary Policy Shocks: What have we learned? NBER Working Paper no. 6400.

Greene, W. (1997), Econometric Analysis, 3th Ed., 1075 pp.

Knell, M., and Stix, H., (2003), How Robust are Money Demand Estimations? A Meta-Analytic Approach, Discussion Paper no. 81, Austrian National Bank.

Lipsey, M., and Wilson, D. (2001), Practical Meta-Analysis, Sage Publications, London.

Lucas, R., (1972), Expectations and the Neutrality of Money, Journal of Economic Theory, 4, no. 2, 103-124.

Lucas, R., (1973), Some International Evidence on Output-Inflation Tradeoffs, American Economic Review, 63, no. 3, 326-334.

Nijkamp, P., and Poot, J., (2004), Meta-Analysis of the effect of fiscal policies on long-run growth, European Journal of Political Economy, Vol. 20, 91-124.

Rose, A. , (2004) The Effect of Common Currencies on International Trade: A MetaAnalysis, in Von Furstenberg, Monetary Unions and Hard Pegs: Effects on Trade, Financial Development and Stability, Oxford University Press.

Sims, C., (1992), Interpreting the Macroeconomic Time Series : The Effects of Monetary Policy, European Economic Review.

Stanley, T. (2001), Wheat from Chaff: Meta-Analysis as Quantitative Literature Review, Journal of Economic Perspectives, 15(3).

Wyplosz, C., (2001), Do We Know How Low Should Inflation Be?, in Herrero, A., Gaspar, V., Hoogduin, L., Morgan, J., Winkler, B., (eds.), Why Price Stability?, First ECB Central Banking Conference, November 2000, Frankfurt, European Central Bank. 


\section{Appendix: Histograms of full samples}

Figure A1: Histogram of short-term output effect

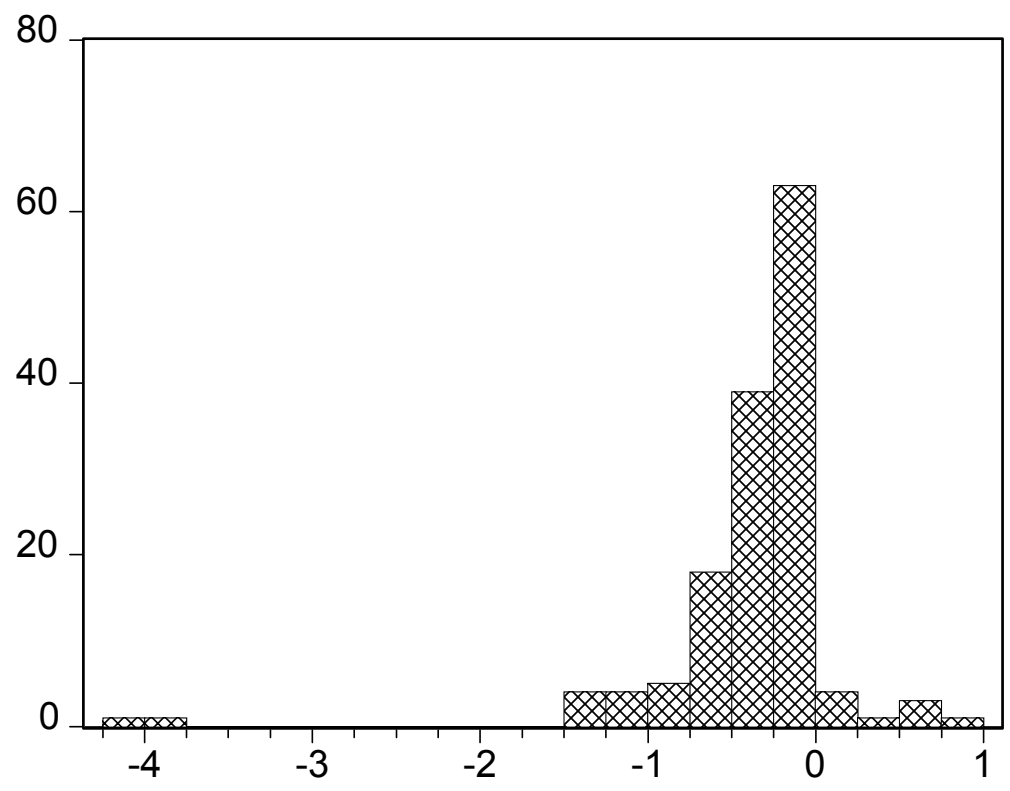

Series: HISTOUTPUTST

Sample 1144

Observations 144

Mean

$-0.379648$

Median

$-0.255000$

Maximum

0.846154

Minimum

$-4.100000$

Std. Dev.

0.556453

Skewness

$-3.749488$

Kurtosis

25.06052

Jarque-Bera

3257.406

Probability

Figure A2: Histogram of long-term output effect

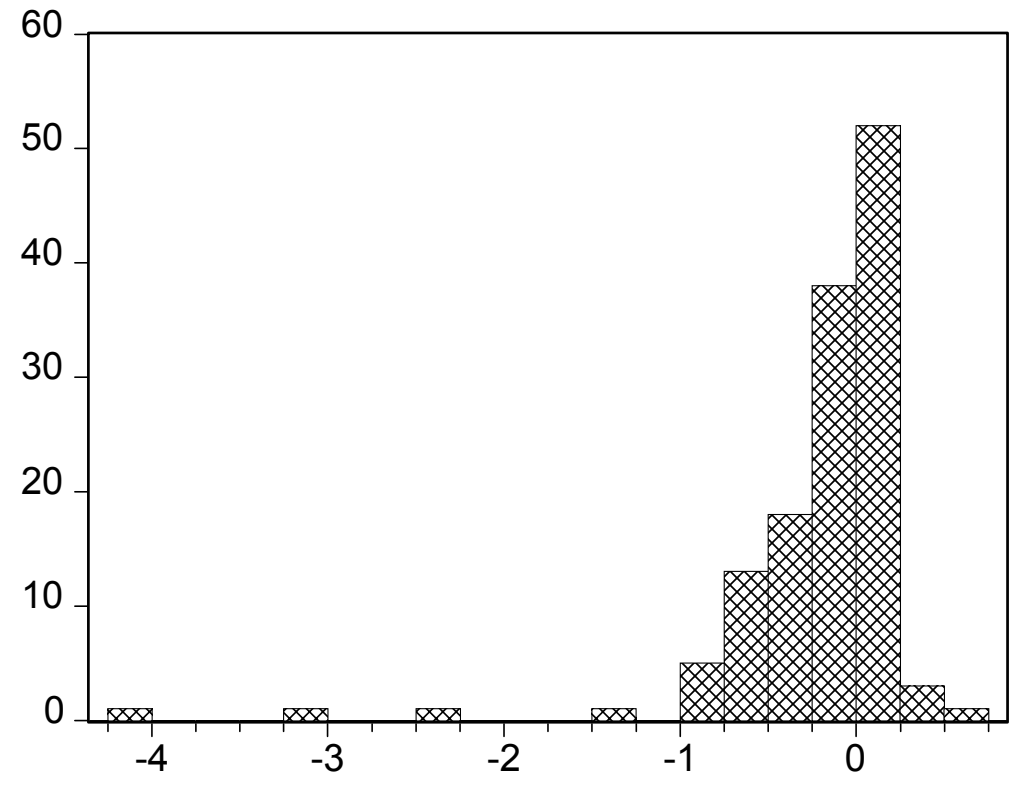

Series: HISTOUTPUTLT

Sample 1144

Observations 134

Mean

$-0.243175$

Median

$-0.081667$

Maximum

0.600000

Minimum

$-4.200000$

Std. Dev.

0.555260

Skewness

$-4.274135$

Kurtosis

26.91657

Jarque-Bera

3601.671

Probability

0.000000 
Figure A3: Histogram of short-term price effect

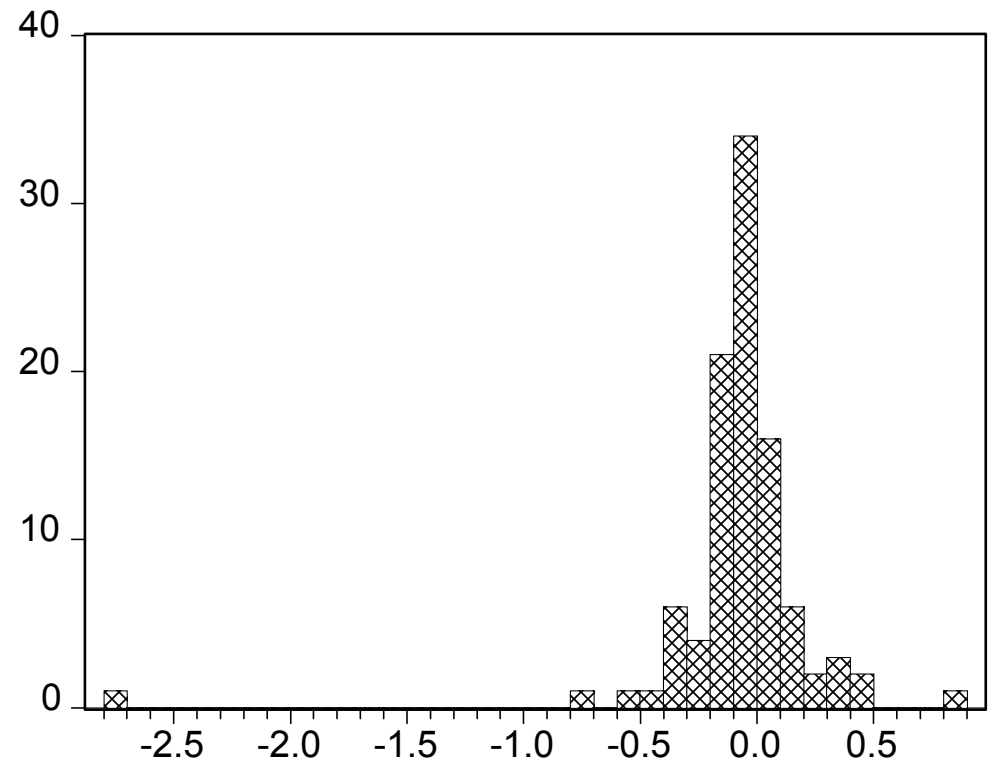

Series: SHORT

Sample 1100

Observations 99

Mean

$-0.092801$

Median

$-0.050000$

Maximum

0.882353

Minimum

$-2.800000$

Std. Dev.

0.344315

Skewness

Kurtosis

40.45842

Jarque-Bera

6157.803

Probability

Figure A4: Histogram of long-term price effect

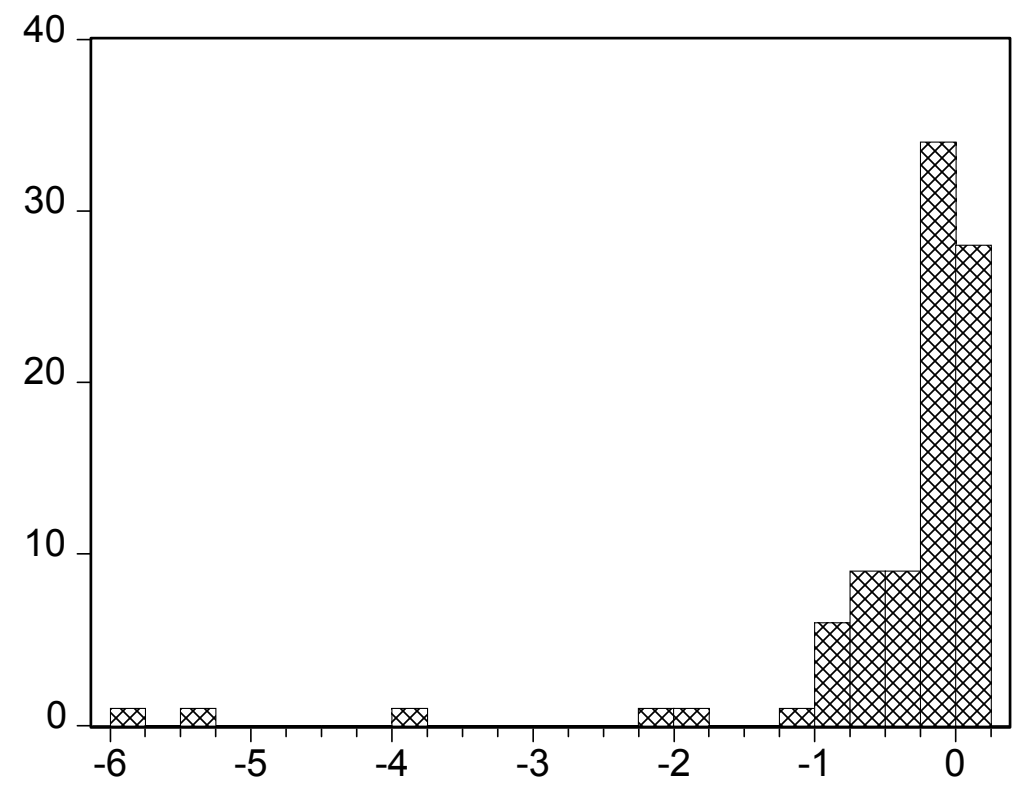

Series: LONG

Sample 199

Observations 92

Mean

$-0.396358$

Median

$-0.115000$

Maximum

0.200000

Minimum

$-6.000000$

Std. Dev.

0.968230

Skewness

$-4.311336$

Kurtosis

22.93889

Jarque-Bera

1808.987

Probability

0.000000 
Figure 5: Frequency distribution of inflation rates

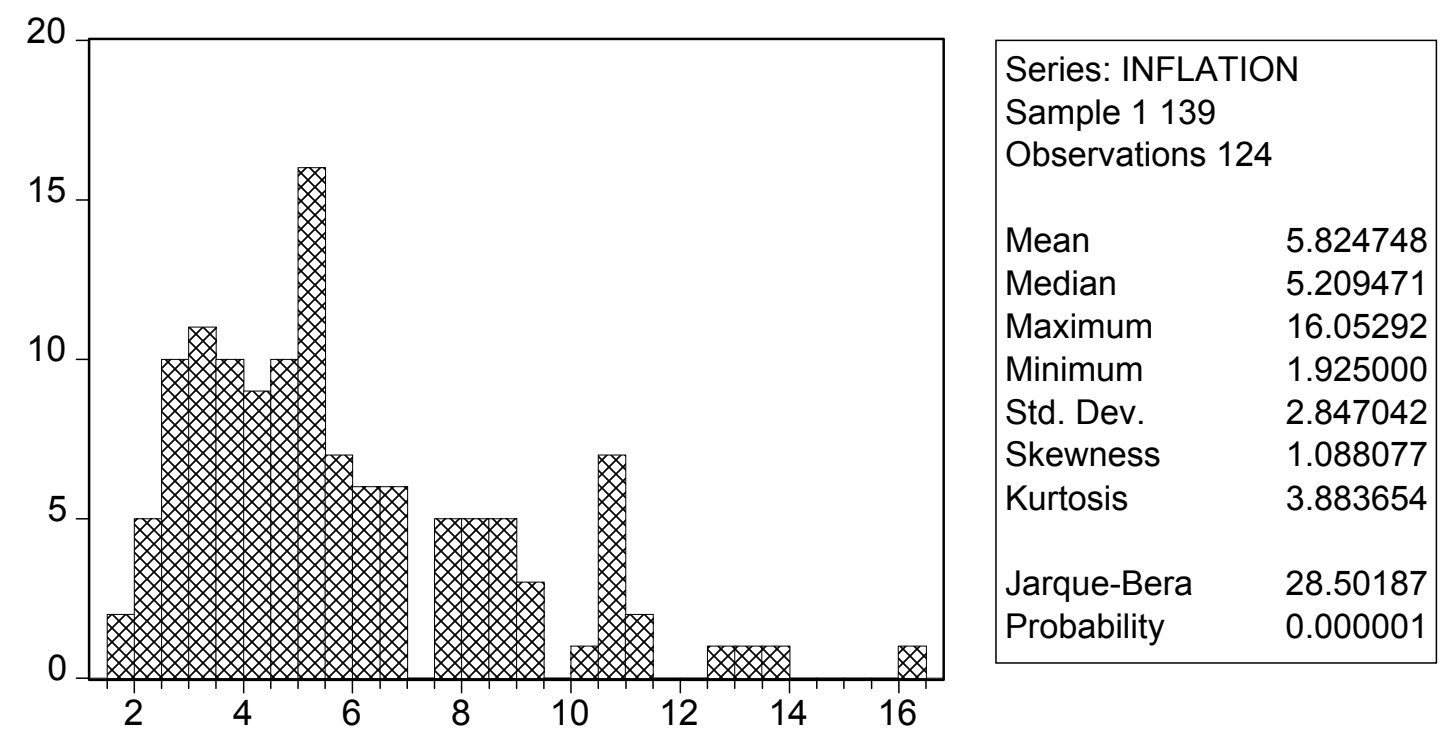




\section{COUNTRY EFFECTS OF MONETARY POLICY}

In this appendix we estimate the country effects without taking into account the macro variables. We do this to obtain estimates of the average output and price effects of monetary policies in the different countries in the sample, without these averages being influenced by macro economic variables. We show the results in tables A1 and A2.

From table A1 we observe, first, that country differences explain about $10 \%$ of the total variation of the short-term output parameters. Second, most country coefficients are negative and statistically different from zero. The exceptions are the emerging countries, Japan, Portugal and Greece whose coefficients are not statistically different from zero.

Table A2 reveals that country differences explain about $14 \%$ of the total variation of the long-term output effects. We find that 12 of the 19 country coefficients are negative and statistically different from zero. In most of the countries with significant coefficients the size of these coefficients is quite large (in absolute value) being of the order of -0.3 to -0.5 . Thus, in a large number of countries a monetary policy shock has a relatively strong and significant effect even after five years. This is quite surprising as one would expect that after five years one comes close to the "long run", a time span over which the output effects of monetary policy should tend to disappear. We also tested whether the country effects are statistically different from each other. In order to do so we applied a Wald test restricting all the country effects to be equal (see table A3). We find that we cannot reject the hypothesis that all country coefficients are equal to each other. This holds for both the short-term and the longterm coefficients.

Tables A4 and A5 present the average country price effects, short-term and long-term. We find that very few of the country effects are significantly different from zero. This may not be surprising for the short-term price effects: the theory predicts that the price effects of monetary policy are weak in the short-run (here one year). However, this result is more surprising for the long-run effects. Only for three countries, France, the UK and the US we find relatively large and statistically significant negative effects.

We performed a joint significance test (Wald test) on these price coefficients and could not reject the null hypothesis that the country effects are the same. 


\begin{tabular}{|c|c|c|c|}
\hline \multicolumn{4}{|c|}{$\begin{array}{l}\text { Table A1: Short- term output paran } \\
\text { country effects } \\
\text { Number of observations: } 142 \\
\end{array}$} \\
\hline Variable & Coefficient & Std. Error & t-Statistic \\
\hline AUSTRIA & -0.361 & 0.137 & -2.61 \\
\hline BELGIUM & -0.251 & 0.149 & -1.68 \\
\hline DENMARK & -0.630 & 0.210 & -2.99 \\
\hline EUROZONE & -0.199 & 0.163 & -1.21 \\
\hline FINLAND & -0.376 & 0.149 & -2.52 \\
\hline FRANCE & -0.368 & 0.101 & -3.64 \\
\hline GERMANY & -0.304 & 0.097 & -3.12 \\
\hline GREECE & -0.410 & 0.365 & -1.12 \\
\hline IRELAND & -0.487 & 0.182 & -2.67 \\
\hline ITALY & -0.356 & 0.094 & -3.78 \\
\hline JAPAN & -0.029 & 0.365 & -0.08 \\
\hline LUXEMBOURG & -0.120 & 0.365 & -0.32 \\
\hline NETHERLANDS & -0.416 & 0.137 & -3.01 \\
\hline PORTUGAL & -0.202 & 0.163 & -1.23 \\
\hline SPAIN & -0.207 & 0.115 & -1.79 \\
\hline SWEDEN & -0.625 & 0.258 & -2.42 \\
\hline UK & -0.280 & 0.121 & -2.30 \\
\hline US & -0.419 & 0.073 & -5.74 \\
\hline EMERGING & -0.052 & 0.129 & -0.40 \\
\hline R-squared & 0.108 & Mean de & gendent var -0.329 \\
\hline
\end{tabular}

\begin{tabular}{|cccc|}
\hline \multicolumn{4}{|c|}{$\begin{array}{c}\text { Table A2: Long- term output } \\
\text { country effects }\end{array}$} \\
$\begin{array}{c}\text { Number of observations: } 127 \\
\text { Variable }\end{array}$ & Coefficient & Std. Error & t-Statistic \\
\hline \hline AUSTRIA & -0.370 & 0.104 & -3.52 \\
BELGIUM & -0.116 & 0.113 & -1.02 \\
DENMARK & -0.050 & 0.160 & -0.31 \\
EUROZONE & -0.091 & 0.138 & -0.66 \\
FINLAND & -0.108 & 0.113 & -0.95 \\
FRANCE & -0.102 & 0.087 & -1.16 \\
GERMANY & -0.214 & 0.087 & -2.44 \\
GREECE & -0.740 & 0.277 & -2.66 \\
IRELAND & -0.067 & 0.138 & -0.48 \\
ITALY & -0.027 & 0.076 & -0.35 \\
JAPAN & 0.000 & 0.277 & 0.00 \\
LUXEMBOURG & -0.150 & 0.277 & -0.54 \\
NETHERLANDS & -0.285 & 0.113 & -2.51 \\
PORTUGAL & -0.164 & 0.124 & -1.32 \\
SPAIN & -0.148 & 0.104 & -1.41 \\
SWEDEN & -0.050 & 0.196 & -0.25 \\
UK & -0.169 & 0.098 & -1.73 \\
US & -0.209 & 0.055 & -3.78 \\
EMERGING & -0.083 & 0.098 & -0.84 \\
\hline \hline R-squared & 0.135 & Mean dependent var & -0.158 \\
\hline
\end{tabular}




\begin{tabular}{|c|c|c|c|}
\hline \multicolumn{4}{|c|}{$\begin{array}{l}\text { Table A3: Test of equality of country output effects } \\
\text { (Wald Test) }\end{array}$} \\
\hline \multicolumn{4}{|c|}{ Short-term effects } \\
\hline F-statistic & 0.360 & Probability & 0.988 \\
\hline Chi-square & 5.763 & Probability & 0.990 \\
\hline \multicolumn{4}{|c|}{ Long-term effects } \\
\hline F-statistic & 1.010 & Probability & 0.451 \\
\hline Chi-square & 16.16 & Probability & 0.441 \\
\hline
\end{tabular}

\begin{tabular}{|c|c|c|c|c|}
\hline \multirow{2}{*}{\multicolumn{5}{|c|}{$\begin{array}{l}\text { Table A4: Short-term price } \\
\text { effects } \\
\text { Included observations: } 98 \\
\text { Variable } \quad \text { Coefficient }\end{array}$}} \\
\hline & & & & \\
\hline AUSTRIA & -0.171 & 0.175 & -0.97 & \\
\hline BELGIUM & -0.075 & 0.175 & -0.42 & \\
\hline DENMARK & -0.200 & 0.350 & -0.57 & \\
\hline FINLAND & -0.136 & 0.202 & -0.67 & \\
\hline FRANCE & -0.022 & 0.123 & -0.18 & \\
\hline GERMANY & -0.014 & 0.110 & -0.13 & \\
\hline GREECE & -0.170 & 0.350 & -0.48 & \\
\hline IRELAND & -0.146 & 0.202 & -0.72 & \\
\hline ITALY & -0.148 & 0.116 & -1.27 & \\
\hline JAPAN & 0.310 & 0.202 & 1.53 & \\
\hline LUXEMBOURG & -0.020 & 0.350 & -0.05 & \\
\hline NETHERLANDS & -0.027 & 0.175 & -0.15 & \\
\hline PORTUGAL & -0.223 & 0.202 & -1.10 & \\
\hline SWEDEN & -0.200 & 0.350 & -0.57 & \\
\hline EMERGING & 0.023 & 0.123 & 0.19 & \\
\hline UK & -0.495 & 0.156 & -3.16 & \\
\hline US & -0.110 & 0.076 & -1.44 & \\
\hline R-squared & 0.142 & Mean de & "Ident var & -0.093 \\
\hline
\end{tabular}

\begin{tabular}{|c|c|c|c|c|}
\hline \multirow{2}{*}{\multicolumn{5}{|c|}{$\begin{array}{l}\text { Table A5: Long-term price } \\
\text { effects } \\
\text { Included observations: } 92 \\
\text { Variable } \quad \text { Coefficient }\end{array}$}} \\
\hline & & & & \\
\hline AUSTRIA & -0.082 & 0.520 & -0.15 & \\
\hline BELGIUM & -0.210 & 0.520 & -0.40 & \\
\hline DENMARK & 0.000 & 1.041 & 0.00 & \\
\hline FINLAND & -0.063 & 0.601 & -0.10 & \\
\hline FRANCE & -0.860 & 0.393 & -2.18 & \\
\hline GERMANY & -0.368 & 0.347 & -1.06 & \\
\hline GREECE & -0.390 & 1.041 & -0.37 & \\
\hline IRELAND & -0.086 & 0.601 & -0.14 & \\
\hline ITALY & -0.125 & 0.368 & -0.34 & \\
\hline JAPAN & -0.631 & 0.601 & -1.05 & \\
\hline LUXEMBOURG & -0.130 & 1.041 & -0.12 & \\
\hline NETHERLANDS & -0.090 & 0.520 & -0.17 & \\
\hline PORTUGAL & -0.183 & 0.601 & -0.30 & \\
\hline SWEDEN & 0.000 & 1.041 & 0.00 & \\
\hline EMERGING & 0.014 & 0.368 & 0.03 & \\
\hline UK & -1.118 & 0.465 & -2.40 & \\
\hline US & -0.437 & 0.227 & -1.92 & \\
\hline R-squared & 0.045 & Mean de & dent var & -0.399 \\
\hline
\end{tabular}




\begin{tabular}{|c|c|c|}
\hline & unweighted data & weighted data \\
\hline \multirow[t]{2}{*}{ AUSTRIA } & -0.993 & -1.764 \\
\hline & -1.292 & -1.575 \\
\hline \multirow[t]{2}{*}{ BELGIUM } & -0.825 & -1.551 \\
\hline & -1.025 & -1.4 \\
\hline \multirow[t]{2}{*}{ DENMARK } & -0.57 & -1.094 \\
\hline & -0.763 & -1.027 \\
\hline \multirow[t]{2}{*}{ EMERGING } & -0.959 & -2.189 \\
\hline & -0.901 & -1.363 \\
\hline \multirow[t]{2}{*}{ EUROZONE } & -0.945 & -2.165 \\
\hline & -1.06 & -1.709 \\
\hline \multirow[t]{2}{*}{ FINLAND } & -0.67 & -1.392 \\
\hline & -0.927 & -1.358 \\
\hline \multirow[t]{2}{*}{ FRANCE } & -1.094 & -2.123 \\
\hline & -1.483 & -1.94 \\
\hline \multirow{2}{*}{ GERMANY } & -1.261 & -2.234 \\
\hline & -1.804 & -2.127 \\
\hline \multirow[t]{2}{*}{ GREECE } & -1.76 & -2.998 \\
\hline & -1.406 & -1.772 \\
\hline \multirow{2}{*}{ IRELAND } & -0.862 & -1.861 \\
\hline & -1.005 & -1.497 \\
\hline \multirow[t]{2}{*}{ ITALY } & -0.843 & -1.857 \\
\hline & -0.952 & -1.387 \\
\hline \multirow[t]{2}{*}{ JAPAN } & -0.871 & -2.431 \\
\hline & -0.756 & -1.352 \\
\hline \multirow[t]{2}{*}{ LUXEMBOURG } & -1.553 & -4.717 \\
\hline & -0.669 & -1.213 \\
\hline \multirow[t]{2}{*}{ NETHERLANDS } & -1.049 & -1.781 \\
\hline & -1.359 & -1.601 \\
\hline \multirow[t]{2}{*}{ PORTUGAL } & -1.212 & -2.749 \\
\hline & -0.978 & -1.487 \\
\hline \multirow[t]{2}{*}{ SPAIN } & -0.959 & -2.095 \\
\hline & -1.009 & -1.46 \\
\hline SWEDEN & -0.735 & -1.304 \\
\hline & -0.871 & -1.09 \\
\hline UK & -1.095 & -1.963 \\
\hline & -1.363 & -1.69 \\
\hline US & -0.958 & -2.012 \\
\hline & -1.386 & -2.032 \\
\hline SVAR & 0.259 & 0.36 \\
\hline & 1.223 & 1.396 \\
\hline ECON & 0.408 & 0.557 \\
\hline & 2.296 & 2.917 \\
\hline GAP & 0.508 & 0.601 \\
\hline & 2.293 & 2.192 \\
\hline IND & 0.237 & 0.306 \\
\hline & 1.225 & 1.297 \\
\hline OPEN & 0.16 & 0.286 \\
\hline & 0.549 & 0.711 \\
\hline SIZE & 0.0001 & 0.0001 \\
\hline & 0.549 & 0.855 \\
\hline PUBDATE & -0.01 & -0.001 \\
\hline & -0.315 & -0.025 \\
\hline BANKING & 0.152 & 0.686 \\
\hline & 0.388 & 0.964 \\
\hline SEVENTIES & -0.1 & -0.403 \\
\hline & -0.372 & -1.314 \\
\hline EIGTHIES & 0.154 & 0.031 \\
\hline & 0.517 & 0.083 \\
\hline INFLATION & 0.047 & 0.107 \\
\hline & 0.81 & 0.107 \\
\hline R-squared & 0.27 & 0.35 \\
\hline Adjusted R-squared & 0.04 & 0.14 \\
\hline Mean dependent var & -0.25 & -0.31 \\
\hline
\end{tabular}




\begin{tabular}{|c|c|c|}
\hline \multicolumn{3}{|c|}{ Table 7: Short-term price coefficients (equation 1) } \\
\hline & unweighted data & weighted data \\
\hline \multirow[t]{2}{*}{ AUSTRIA } & 0.432 & 0.619 \\
\hline & 0.806 & 1.023 \\
\hline \multirow[t]{2}{*}{ BELGIUM } & 0.647 & 0.827 \\
\hline & 1.171 & 1.331 \\
\hline \multirow[t]{2}{*}{ DENMARK } & 0.467 & 0.748 \\
\hline & 0.803 & 0.916 \\
\hline \multirow[t]{2}{*}{ EMERGING } & 0.575 & 0.816 \\
\hline & 0.848 & 0.968 \\
\hline \multirow[t]{2}{*}{ EUROZONE } & 0.614 & 0.769 \\
\hline & 0.982 & 1.086 \\
\hline \multirow[t]{2}{*}{ FINLAND } & 0.53 & 0.564 \\
\hline & 1.062 & 0.986 \\
\hline \multirow[t]{2}{*}{ FRANCE } & 0.46 & 0.56 \\
\hline & 0.908 & 0.919 \\
\hline \multirow[t]{2}{*}{ GERMANY } & 0.46 & 0.418 \\
\hline & 0.932 & 0.736 \\
\hline \multirow[t]{2}{*}{ GREECE } & 0.513 & 0.854 \\
\hline & 0.603 & 0.878 \\
\hline \multirow[t]{2}{*}{ IRELAND } & 0.574 & 0.888 \\
\hline & 0.977 & 1.253 \\
\hline \multirow[t]{2}{*}{ ITALY } & 0.358 & 0.606 \\
\hline & 0.585 & 0.817 \\
\hline \multirow[t]{2}{*}{ JAPAN } & 0.698 & 0.688 \\
\hline & 1.021 & 0.79 \\
\hline \multirow[t]{2}{*}{ LUXEMBOURG } & 0.774 & 0.377 \\
\hline & 0.508 & 0.191 \\
\hline \multirow[t]{2}{*}{ NETHERLANDS } & 0.672 & 0.766 \\
\hline & 1.237 & 1.237 \\
\hline \multirow[t]{2}{*}{ PORTUGAL } & 0.551 & 0.931 \\
\hline & 0.652 & 0.902 \\
\hline \multirow[t]{2}{*}{ SPAIN } & 0.498 & 0.738 \\
\hline & 0.826 & 0.997 \\
\hline SWEDEN & 0.482 & 0.806 \\
\hline & 0.776 & 0.937 \\
\hline UK & 0.006 & 0.116 \\
\hline & 0.01 & 0.169 \\
\hline Us & 0.018 & -0.005 \\
\hline & 0.034 & -0.008 \\
\hline SVAR & -0.243 & -0.408 \\
\hline & -1.831 & -2.927 \\
\hline ECON & -0.085 & -0.114 \\
\hline & -0.556 & -0.791 \\
\hline OPEN & -0.074 & -0.156 \\
\hline & -0.375 & -0.665 \\
\hline SIZE & 0 & 0.0001 \\
\hline & 0.711 & 1.133 \\
\hline PUBDATE & -0.01 & -0.013 \\
\hline & -0.381 & -0.589 \\
\hline BANKING & -0.033 & 0.103 \\
\hline & -0.132 & 0.289 \\
\hline SEVENTIES & -0.282 & -0.322 \\
\hline & -1.197 & -1.513 \\
\hline EIGHTIES & -0.253 & -0.33 \\
\hline & -1.112 & -1.38 \\
\hline INFLATION & -0.012 & -0.034 \\
\hline & -0.27 & -0.63 \\
\hline R-squared & 0.27 & 0.36 \\
\hline Adjusted R-squared & 0.06 & 0.09 \\
\hline Mean dependent var & -0.098 & -0.096 \\
\hline
\end{tabular}




\begin{tabular}{|c|c|c|}
\hline & unweighted data & weighted data \\
\hline \multirow[t]{2}{*}{ AUSTRIA } & -0.234 & -0.02 \\
\hline & -0.168 & -0.011 \\
\hline \multirow[t]{2}{*}{ BELGIUM } & -0.151 & 0.262 \\
\hline & -0.105 & 0.137 \\
\hline \multirow[t]{2}{*}{ DENMARK } & -0.348 & -0.151 \\
\hline & -0.235 & -0.064 \\
\hline \multirow[t]{2}{*}{ EMERGING } & -0.108 & 0.29 \\
\hline & -0.059 & 0.108 \\
\hline \multirow[t]{2}{*}{ EUROZONE } & -5.02 & -4.925 \\
\hline & -3.327 & -2.415 \\
\hline \multirow[t]{2}{*}{ FINLAND } & -0.046 & 0.401 \\
\hline & -0.035 & 0.226 \\
\hline \multirow[t]{2}{*}{ FRANCE } & -1.38 & -1.505 \\
\hline & -1.055 & -0.806 \\
\hline \multirow[t]{2}{*}{ GERMANY } & -0.995 & -0.997 \\
\hline & -0.8 & -0.586 \\
\hline \multirow[t]{2}{*}{ GREECE } & -0.385 & 0.05 \\
\hline & -0.173 & 0.017 \\
\hline \multirow[t]{2}{*}{ IRELAND } & -0.051 & 0.388 \\
\hline & -0.033 & 0.176 \\
\hline \multirow[t]{2}{*}{ ITALY } & -0.617 & -0.236 \\
\hline & -0.386 & -0.103 \\
\hline \multirow[t]{2}{*}{ JAPAN } & -2.451 & -2.5 \\
\hline & -1.474 & -0.995 \\
\hline \multirow[t]{2}{*}{ LUXEMBOURG } & -1.07 & -2.425 \\
\hline & -0.279 & -0.418 \\
\hline \multirow[t]{2}{*}{ NETHERLANDS } & -0.23 & -0.058 \\
\hline & -0.164 & -0.03 \\
\hline \multirow[t]{2}{*}{ PORTUGAL } & -0.357 & -0.027 \\
\hline & -0.16 & -0.008 \\
\hline \multirow[t]{2}{*}{ SPAIN } & -0.467 & -0.446 \\
\hline & -0.278 & -0.184 \\
\hline \multirow[t]{2}{*}{ SWEDEN } & -0.395 & -0.137 \\
\hline & -0.248 & -0.055 \\
\hline \multirow[t]{2}{*}{ UK } & -1.075 & -0.928 \\
\hline & -0.717 & -0.439 \\
\hline US & -3.277 & -3.064 \\
\hline & -2.669 & -1.859 \\
\hline SVAR & 0.652 & 0.558 \\
\hline & 2.095 & 1.485 \\
\hline ECON & 0.709 & 0.915 \\
\hline & 1.926 & 2.352 \\
\hline OPEN & -0.02 & -0.142 \\
\hline & -0.043 & -0.217 \\
\hline SIZE & 0.0006 & 0.0006 \\
\hline & 3.326 & 2.94 \\
\hline PUBDATE & 0.078 & 0.021 \\
\hline & 1.322 & 0.345 \\
\hline BANKING & 0.246 & 0.622 \\
\hline & 0.399 & 0.623 \\
\hline SEVENTIES & -1.93 & -1.858 \\
\hline & -3.422 & -3.205 \\
\hline EIGHTIES & -1.204 & -0.991 \\
\hline & -2.013 & -1.411 \\
\hline INFLATION & 0.011 & -0.014 \\
\hline & 0.09 & -0.08 \\
\hline R-squared & 0.48 & 0.5 \\
\hline Adjusted R-squared & 0.23 & 0.26 \\
\hline Mean dependent var & -0.4 & -0.49 \\
\hline
\end{tabular}




\section{CESifo Working Paper Series}

(for full list see www.cesifo.de)

1160 Romain Ranciere, Aaron Tornell, and Frank Westermann, Crises and Growth: A ReEvaluation, March 2004

1161 Assaf Razin and Efraim Sadka, Transparency, Specialization and FDI, March 2004

1162 Ludger Woessmann, How Equal Are Educational Opportunities? Family Background and Student Achievement in Europe and the United States, March 2004

1163 B.M.S. van Praag and Barbara E. Baarsma, Using Happiness Surveys to Value Intangibles: The Case of Airport Noise, March 2004

1164 Aaron Tornell, Frank Westermann, and Lorenza Martínez, The Positive Link Between Financial Liberalization, Growth, and Crises, March 2004

1165 Helge Berger and Carsten Hefeker, One Country, One Vote? Labor Market Structure and Voting Rights in the ECB, March 2004

1166 Clemens Fuest and Martin Kolmar, A Theory of User-Fee Competition, March 2004

1167 Friedrich Schneider and Robert Klinglmair, Shadow Economies around the World: What Do We Know?, April 2004

1168 Horst Raff and Nicolas Schmitt, Exclusive Dealing and Common Agency in International Markets, April 2004

1169 M. Hashem Pesaran and Allan Timmermann, Real Time Econometrics, April 2004

1170 Sean D. Barrett, Privatisation in Ireland, April 2004

1171 V. Anton Muscatelli, Patrizio Tirelli and Carmine Trecroci, Can Fiscal Policy Help Macroeconomic Stabilisation? Evidence from a New Keynesian Model with Liquidity Constraints, April 2004

1172 Bernd Huber and Marco Runkel, Tax Competition, Excludable Public Goods and User Charges, April 2004

1173 John McMillan and Pablo Zoido, How to Subvert Democracy: Montesinos in Peru, April 2004

1174 Theo Eicher and Jong Woo Kang, Trade, Foreign Direct Investment or Acquisition: Optimal Entry Modes for Multinationals, April 2004

1175 Chang Woon Nam and Doina Maria Radulescu, Types of Tax Concessions for Attracting Foreign Direct Investment in Free Economic Zones, April 2004 
1176 M. Hashem Pesaran and Andreas Pick, Econometric Issues in the Analysis of Contagion, April 2004

1177 Steinar Holden and Fredrik Wulfsberg, Downward Nominal Wage Rigidity in Europe, April 2004

1178 Stefan Lachenmaier and Ludger Woessmann, Does Innovation Cause Exports? Evidence from Exogenous Innovation Impulses and Obstacles, April 2004

1179 Thiess Buettner and Johannes Rincke, Labor Market Effects of Economic Integration The Impact of Re-Unification in German Border Regions, April 2004

1180 Marko Koethenbuerger, Leviathans, Federal Transfers, and the Cartelization Hypothesis, April 2004

1181 Michael Hoel, Tor Iversen, Tore Nilssen, and Jon Vislie, Genetic Testing and Repulsion from Chance, April 2004

1182 Paul De Grauwe and Gunther Schnabl, Exchange Rate Regimes and Macroeconomic Stability in Central and Eastern Europe, April 2004

1183 Arjan M. Lejour and Ruud A. de Mooij, Turkish Delight - Does Turkey's accession to the EU bring economic benefits?, May 2004

1184 Anzelika Zaiceva, Implications of EU Accession for International Migration: An Assessment of Potential Migration Pressure, May 2004

1185 Udo Kreickemeier, Fair Wages and Human Capital Accumulation in a Global Economy, May 2004

1186 Jean-Pierre Ponssard, Rent Dissipation in Repeated Entry Games: Some New Results, May 2004

1187 Pablo Arocena, Privatisation Policy in Spain: Stuck Between Liberalisation and the Protection of Nationals' Interests, May 2004

1188 Günter Knieps, Privatisation of Network Industries in Germany: A Disaggregated Approach, May 2004

1189 Robert J. Gary-Bobo and Alain Trannoy, Efficient Tuition Fees, Examinations, and Subsidies, May 2004

1190 Saku Aura and Gregory D. Hess, What's in a Name?, May 2004

1191 Sjur Didrik Flåm and Yuri Ermoliev, Investment Uncertainty, and Production Games, May 2004

1192 Yin-Wong Cheung and Jude Yuen, The Suitability of a Greater China Currency Union, May 2004 
1193 Inés Macho-Stadler and David Pérez-Castrillo, Optimal Enforcement Policy and Firms' Emissions and Compliance with Environmental Taxes, May 2004

1194 Paul De Grauwe and Marianna Grimaldi, Bubbles and Crashes in a Behavioural Finance Model, May 2004

1195 Michel Berne and Gérard Pogorel, Privatization Experiences in France, May 2004

1196 Andrea Galeotti and José Luis Moraga-González, A Model of Strategic Targeted Advertising, May 2004

1197 Hans Gersbach and Hans Haller, When Inefficiency Begets Efficiency, May 2004

1198 Saku Aura, Estate and Capital Gains Taxation: Efficiency and Political Economy Consideration, May 2004

1199 Sandra Waller and Jakob de Haan, Credibility and Transparency of Central Banks: New Results Based on Ifo's World Economicy Survey, May 2004

1200 Henk C. Kranendonk, Jan Bonenkamp, and Johan P. Verbruggen, A Leading Indicator for the Dutch Economy - Methodological and Empirical Revision of the CPB System, May 2004

1201 Michael Ehrmann, Firm Size and Monetary Policy Transmission - Evidence from German Business Survey Data, May 2004

1202 Thomas A. Knetsch, Evaluating the German Inventory Cycle - Using Data from the Ifo Business Survey, May 2004

1203 Stefan Mittnik and Peter Zadrozny, Forecasting Quarterly German GDP at Monthly Intervals Using Monthly IFO Business Conditions Data, May 2004

1204 Elmer Sterken, The Role of the IFO Business Climate Indicator and Asset Prices in German Monetary Policy, May 2004

1205 Jan Jacobs and Jan-Egbert Sturm, Do Ifo Indicators Help Explain Revisions in German Industrial Production?, May 2004

1206 Ulrich Woitek, Real Wages and Business Cycle Asymmetries, May 2004

1207 Burkhard Heer and Alfred Maußner, Computation of Business Cycle Models: A Comparison of Numerical Methods, June 2004

1208 Costas Hadjiyiannis, Panos Hatzipanayotou, and Michael S. Michael, Pollution and Capital Tax Competition within a Regional Block, June 2004

1209 Stephan Klasen and Thorsten Nestmann, Population, Population Density, and Technological Change, June 2004

1210 Wolfgang Ochel, Welfare Time Limits in the United States - Experiences with a New Welfare-to-Work Approach, June 2004 
1211 Luis H. R. Alvarez and Erkki Koskela, Taxation and Rotation Age under Stochastic Forest Stand Value, June 2004

1212 Bernard M. S. van Praag, The Connexion Between Old and New Approaches to Financial Satisfaction, June 2004

1213 Hendrik Hakenes and Martin Peitz, Selling Reputation When Going out of Business, June 2004

1214 Heikki Oksanen, Public Pensions in the National Accounts and Public Finance Targets, June 2004

1215 Ernst Fehr, Alexander Klein, and Klaus M. Schmidt, Contracts, Fairness, and Incentives, June 2004

1216 Amihai Glazer, Vesa Kanniainen, and Panu Poutvaara, Initial Luck, Status-Seeking and Snowballs Lead to Corporate Success and Failure, June 2004

1217 Bum J. Kim and Harris Schlesinger, Adverse Selection in an Insurance Market with Government-Guaranteed Subsistence Levels, June 2004

1218 Armin Falk, Charitable Giving as a Gift Exchange - Evidence from a Field Experiment, June 2004

1219 Rainer Niemann, Asymmetric Taxation and Cross-Border Investment Decisions, June 2004

1220 Christian Holzner, Volker Meier, and Martin Werding, Time Limits on Welfare Use under Involuntary Unemployment, June 2004

1221 Michiel Evers, Ruud A. de Mooij, and Herman R. J. Vollebergh, Tax Competition under Minimum Rates: The Case of European Diesel Excises, June 2004

1222 S. Brock Blomberg and Gregory D. Hess, How Much Does Violence Tax Trade?, June 2004

1223 Josse Delfgaauw and Robert Dur, Incentives and Workers' Motivation in the Public Sector, June 2004

1224 Paul De Grauwe and Cláudia Costa Storti, The Effects of Monetary Policy: A MetaAnalysis, June 2004 